\title{
Influence of debris cover and altitude on glacier surface melting: a case study on Dokriani Glacier, central Himalaya, India
}

\author{
Bhanu PRATAP, D.P. DOBHAL, Manish MEHTA, Rakesh BHAMBRI \\ Centre for Glaciology, Wadia Institute of Himalayan Geology, Dehra Dun, India \\ Correspondence: Bhanu Pratap <bhanuglacio@gmail.com>
}

\begin{abstract}
Most of the central Himalayan glaciers have surface debris layers of variable thickness, which greatly affect the ablation rate. An attempt has been made to relate debris-cover thickness to glacier surface melting. Thirty stakes were used to calculate ablation for debris-covered and clean ice of Dokriani Glacier $\left(7 \mathrm{~km}^{2}\right)$ from $2009 / 10$ to $2012 / 13$. Our study revealed significant altitude-wise difference in the rate of clean and debris-covered ice melting. We found a high correlation $\left(R^{2}=0.92\right)$ between mean annual clean-ice ablation and altitude, and a very low correlation $\left(R^{2}=0.14\right)$ between debris-covered ice melting and altitude. Debris-covered ice ablation varies with variation in debris thickness from 1 to $40 \mathrm{~cm}$; ablation was maximum under debris thicknesses of 1-6 cm and minimum under $40 \mathrm{~cm}$. Even a small debris-cover thickness $(1-2 \mathrm{~cm})$ reduces ice melting as compared to that of clean ice on an annual basis. Overall, debris-covered ice ablation during the study period was observed to be $37 \%$ less than clean-ice ablation. Strong downwasting was also observed in the Dokriani Glacier ablation area, with average annual ablation of $1.82 \mathrm{~m}$ w.e. $\mathrm{a}^{-1}$ in a similar period. Our study suggests that a thinning glacier rapidly becomes debris-covered over the ablation area, reducing the rate of ice loss.
\end{abstract}

KEYWORDS: climate change, debris-covered glaciers, glacier ablation phenomena

\section{INTRODUCTION}

Himalayan glaciers are classified as clean-ice type (C-type) and debris-covered ice type (D-type) (Moribayashi and Higuchi, 1977; Shroder and others, 2000). Debris- or moraine-covered glaciers are a significant sediment transport agent in cold mountainous environments (Kirkbride, 1995). Debris over the ablation zone generally originates from rockfall from the adjacent valley mountain, erosion from elevated lateral moraines, avalanches, and debris entrainment through englacial channels (Hambrey and others, 1999; Hewitt, 2009; Benn and others, 2012). An understanding of debris cover is important for mass balance and glacier dynamics as debris thickness determines the icemelt rate (Mattson and others, 1993; Zhang and others, 2011). For example, thick debris-covered glaciers respond more slowly to climatic changes than glaciers with thinner debris covers or clean glaciers (Mattson, 2000; Singh and others, 2000; Scherler and others, 2011).

Existing studies suggest that $70-80 \%$ of Himalayan glaciers are debris-covered and have been receding almost since the end of the Little Ice Age (Mayewski and Jeschke, 1979; Sakai and others, 2000; Dobhal and others, 2004; Casey and others, 2012). Most of the research work on debriscovered Himalayan glaciers has concentrated on mapping, mass balance and its temporal variations based on remote sensing (Berthier and others, 2007; Bolch and others, 2008, 2011; Racoviteanu and others, 2008; Shukla and others, 2009; Bhambri and others, 2011, 2012; Kulkarni and others, 2011; Scherler and others, 2011; Casey and others, 2012).

Much less attention has been paid to quantifying debriscover effects on the mass-balance process and its response to climate change using ground-based glaciological methods (Adhikary and others, 2000; Singh and others, 2000; Raina 2009; Dobhal and others, 2013). Additionally, the influence of debris cover on the ablation process in different seasons (e.g. winter, spring and monsoon) is largely unknown. Therefore, understanding the impact of debriscover thickness on ablation is of paramount interest among glaciologists especially over the Himalayan glaciers.

Experimental and short-period (ablation season) studies suggest that a thick debris cover reduces ablation, whereas a thin debris layer increases ice melt underneath (Mattson and others, 1993; Mattson, 2000; Sakai and others, 2000; Singh and others, 2000; Raina 2009; Reznichenko and others, 2010; Zhang and others, 2011). The critical thickness that alters the ablation rate varies greatly from glacier to glacier, as well as from one point to another even on the same glacier (Kirkbride and Dugmore, 2003). An experimental study by Reznichenko and others (2010) reported that $>50 \mathrm{~mm}$ thick debris reduces the total heat flux to the ice surface underneath. Mattson and others (1993) reported an increase in ablation under $0-10 \mathrm{~mm}$ of debris on debriscovered Rakhiot Glacier, Punjab Himalaya. They also found that $30 \mathrm{~mm}$ of debris tends to be a critical thickness which suppresses the ablation process as compared to clean ice. These measurements are complemented by Kayastha and others (2000) who predicted ice melting at different thickness levels beneath variably thick debris cover on Khumbu Glacier, Nepal Himalaya. Kayastha and others (2000) also showed that maximum ablation occurs when the fine debris layer over the bare ice is $\sim 0.3 \mathrm{~cm}$ thick and that ablation decreases when debris becomes thicker than $5 \mathrm{~cm}$.

Some other noteworthy numerical models have also been developed for understanding the insulating effect of debris cover on ice melt. These are generally based on energy balance on the debris layer using meteorological parameters and thermal conductivity of the debris layer as a function of its thickness (Kayastha and others, 2000; Nicholson and Benn, 2006, 2013). In addition, previous studies have described the role of debris thickness in the lower regions of 


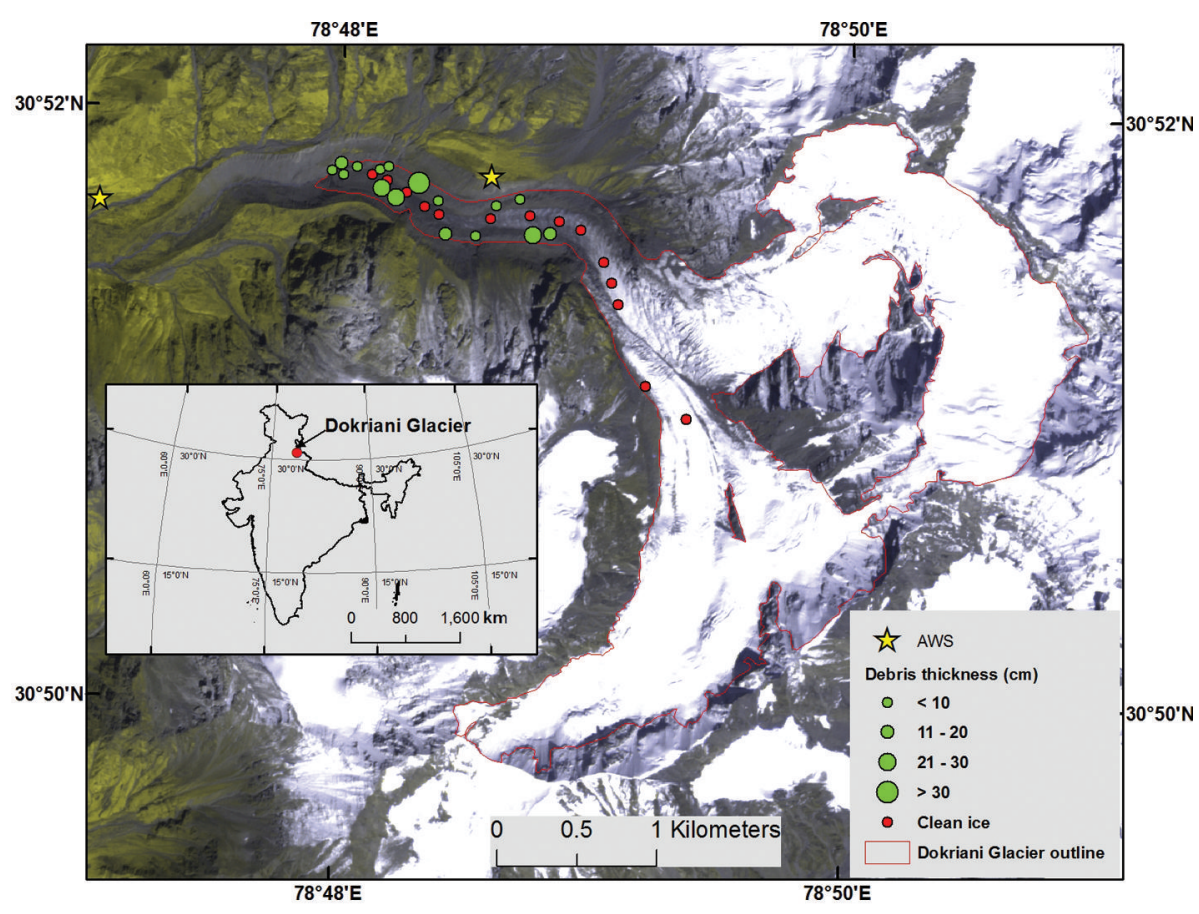

Fig. 1. Location map of Dokriani Glacier, central Himalaya, India. Background is based on Resourcesat 2 Linear Imaging Self-Scanning sensor (LISS) IV, 20 September 2013 (spatial resolution $5.8 \mathrm{~m}$ ), band combination 3-3-1. Circles over the glacier surface represent the ablation stakes and associated debris thickness. Star shows location of automatic weather station.

glaciers which can reduce the retreat rate but can lead to fragmentation of the snout (Kulkarni and others 2007; Basnett and others, 2013; Dobhal and others 2013).

Observations of sub-debris ice ablation and debris cover enhancement as a function of ablation are site-specific and are highly dependent on the prevailing atmospheric conditions (Nicholson and Benn, 2006). In view of this, we investigated the ablation rate under varying debris-cover thickness in relation to the distinct altitude of Dokriani Glacier, central Himalaya, India, for the period 2009/10$2012 / 13$ and analysed glacier behaviour in response to annual atmospheric conditions. Our study also provides an overview of the spatial and temporal distribution of debris cover in the lower ablation zone.

\section{STUDY AREA}

Dokriani Glacier is a valley glacier formed by two cirques, one on the northern slopes of Draupadi Ka Danda (5716 m a.s.l.) and the other on the western slopes of Janoli Peak (6632 m a.s.l.) (Fig. 1). It flows north-northwestwards for $2.0 \mathrm{~km}$ up to the base of the icefall, from where it turns westwest-northwards and flows for another $3.0 \mathrm{~km}$ before terminating at $3965 \mathrm{ma.s.l}$. The Din Gad tributary of Bhagirathi River originates from the snout of Dokriani Glacier (3965 ma.s.I.). It has a catchment area of $77.8 \mathrm{~km}^{2}$, of which $7 \mathrm{~km}^{2}$ is glacierized. This catchment area is one of the beststudied glacierized basins in the Himalaya in terms of mass balance, recession, hydrological and meteorological research (Thayyen and others, 2005; Singh and others, 2007; Dobhal and others 2008; Thayyen and Gergan 2010; Pratap and others, 2013). Previous studies have revealed that Dokriani Glacier has experienced continuous negative mass balance and extensive retreat since 1962 (Dobhal and others 2008; Dobhal and Mehta, 2010). The ground-based mass-balance study for Dokriani Glacier was conducted during the 1990s, and average equilibrium-line altitude (ELA) during the study period was at 5070 ma.s.l. (Dobhal and others, 2008). Dokriani Glacier retreated $838 \mathrm{~m}$ at an average rate of $16.4 \mathrm{~m} \mathrm{a}^{-1}$ during 1962-2007 (Dobhal and others, 2004; Dobhal and Mehta, 2010). About 20\% of its ablation area is covered with debris, enclosed by highly elevated right lateral and left lateral moraines (Fig. 1). The centre line of the Dokriani Glacier ablation zone comprises clean ice, while the undistributed debris cover is located along the side margins (Figs 1 and 2). Geologically, the study area is located in the north of the Pindari Thrust and comprises calc silicate rocks, biotite gneisses, and schists with granite, pegmatite and apatite veins belonging to the Pindari Formation (Valdiya and others, 1999). Accordingly, the debris over the Dokriani Glacier consists of gneisses, granite and schist.

\section{METHODOLOGY}

To determine the effects of a supraglacial debris cover of varying thickness on glacier ice melt, ablation was measured for four consecutive years (2009/10-2012/13). At the end of October every year during the study period, 30 ablation stakes were drilled into the debris-covered and clean-ice portions of Dokriani Glacier to quantify ablation (Fig. 1). International protocols for ablation measurements based on glaciological methods (Østrem and Brugman, 1991; Cogley and others, 2011) were followed. Ablation at each stake was monitored at 15 day intervals during the ablation season, and winter melting was calculated based on cumulative melting from 1 November to 30 April in order to determine net winter, net summer and monthly ablation. As this glacier had varying debris thickness as well as clean ice in every $100 \mathrm{~m}$, ablation stakes were installed such that each stake could represent the specific glacier area (i.e. debris-covered area or bare-ice area) (Fig. 1). Net ablation was computed based on 

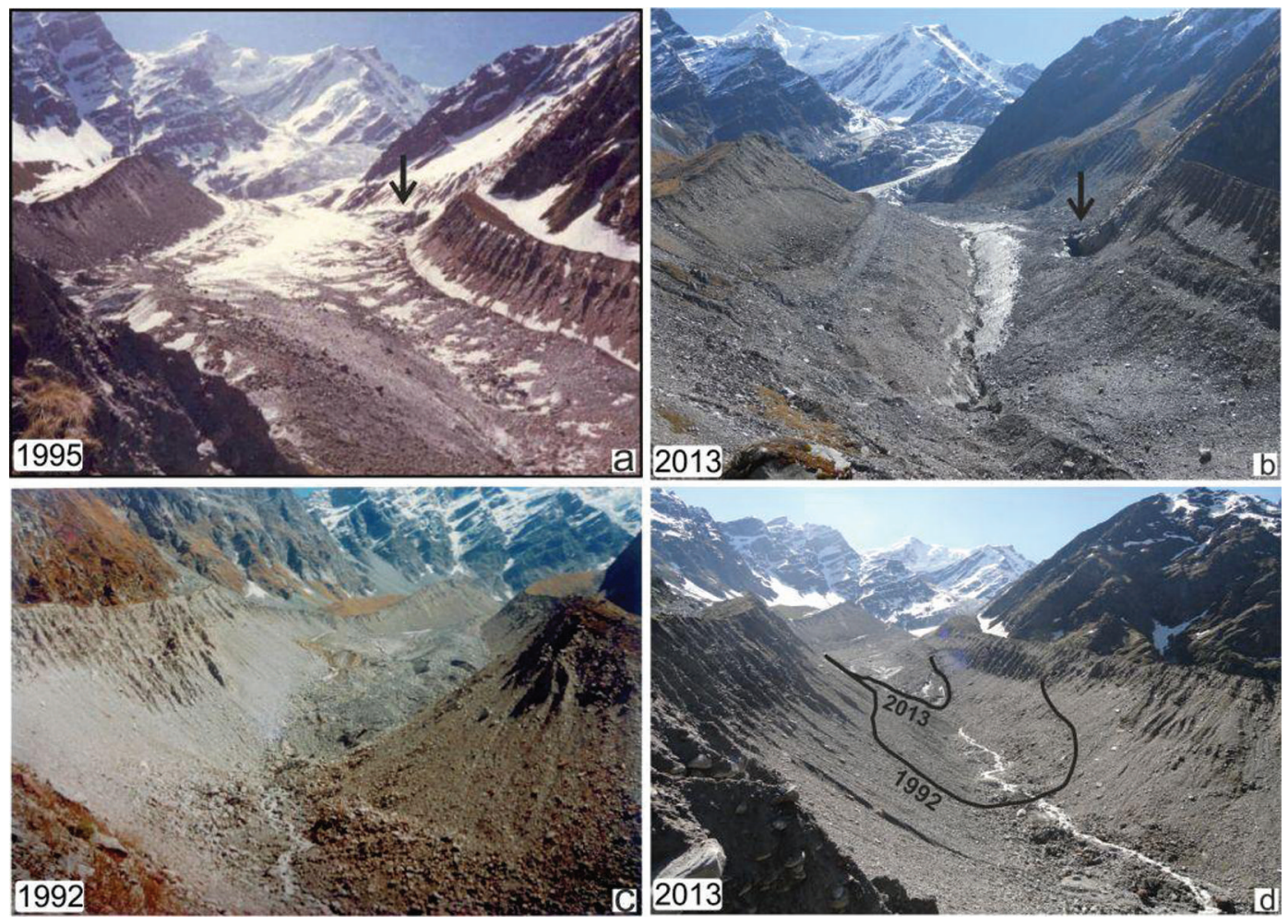

Fig. 2. Temporal changes in debris cover, landform and surface morphology of Dokriani Glacier: (a) ablation zone in 1995 and (b) 2013 glacier surface show substantial surface lowering; (c, d) glacier extension in (c) 1992 and (d) 2013 shows recession and debris enhancement over terminus.

ice thickness loss multiplied by ice density. Ice density was measured at various points over the Dokriani Glacier ablation zone, and an average density of $850 \mathrm{~kg} \mathrm{~m}^{-3}$ was calculated for assessing water equivalent ice ablation.

Generally, a reading problem arises for stakes placed near the side-walls of the lateral moraines because debris fall from moraines can affect the measurements. In the study area the lateral moraines reach $40-60 \mathrm{~m}$ above the glacier surface, indicating significant glacier downwasting in recent decades (Fig. 2). Moreover, the debris cover consists of large boulders with a greater possibility of shifting in an undulating manner which can hamper the stake reading. To minimize the effect of these factors, stake networks were laid with due caution for making observations.

\section{RESULTS AND DISCUSSION}

\section{Debris-covered and clean-ice melting}

A total of 30 ablation stakes were emplaced, 16 in the debris-covered ice and 14 in the clean ice of Dokriani Glacier for 4 years (2009/10-2012/13). In situ survey for supraglacial debris thickness and coverage measurement indicated that the debris cover was limited to the ablation zone between 3900 and 4400 ma.s.l. (Fig. 1). The observed annual ablation at the stakes in clean ice and in debriscovered ice of varying thickness is presented in Figure 3. We found a strong positive correlation between mean annual ablation of clean ice and elevation $\left(R^{2} \geq 0.92\right)$ during the study period. The maximum clean-ice melting $\left(4.9\right.$ m w.e. $\left.\mathrm{a}^{-1}\right)$ was observed near the snout between 4000 and $4200 \mathrm{~m}$ a.s.l. from $2009 / 10$ to $2012 / 13$. The clean-ice melting decreases with increasing elevation and reaches 0.34 mw.e. $\mathrm{a}^{-1}$ at $4900-5000$ ma.s.l. near the ELA. The observed clean-ice melt rate at different elevations revealed the role of temperature lapse rate (which is also linear with elevation). Pratap and others (2013) observed an average monthly temperature lapse rate of $6.56^{\circ} \mathrm{C} \mathrm{km}^{-1}$ between 3800 and $4400 \mathrm{~m}$ a.s.I., higher than the basin average lapse rate $\left(6.0^{\circ} \mathrm{C} \mathrm{km}^{-1}\right)$. This occurs due to the high temperature gradient between two elevations, where the ice surface is exposed earlier at lower elevation than at snow-covered higher elevation. At higher elevations, therefore, the melting of ice (underneath the snow cover) is delayed.

Conversely, inconsistent ablation was observed in debriscovered ice where debris thickness ranged from 1 to $40 \mathrm{~cm}$. We found a low correlation between debris-covered ice and altitude $\left(R^{2}=0.14\right)$ (Fig. 3). This is due to the insulation effects of inhomogeneous distribution (variable thickness) of debris irrespective of altitudinal variation. Ablation measurements also show that debris-covered ice had a lower melt rate than clean ice (Fig. 3). Annual ablation measurements in areas between 3900 and $4400 \mathrm{~m}$ a.s. I. from the initial visit in October 2009 to the end of the 2013 ablation season show that the difference in ablation rates of debris-covered and clean ice varies between $27 \%$ and $44 \%$ (average $37 \%$ ) on Dokriani Glacier (Table 1). Furthermore, we found that even a small debris-cover thickness $(1-2 \mathrm{~cm})$ retards melting compared to that of clean ice on an annual basis. Thus, no evidence was found to support increased ablation under a fine debris thickness compared to clean ice.

The relative difference between melting of debriscovered and clean ice was lowest in 2012/13. However, the absolute value of melting was higher in that year than in other years during the study period (Table 1). This is owing to the development of a supraglacial meltwater channel along the centre line during 2012/13, which contributed proportionally higher ice melt (Fig. 4). 

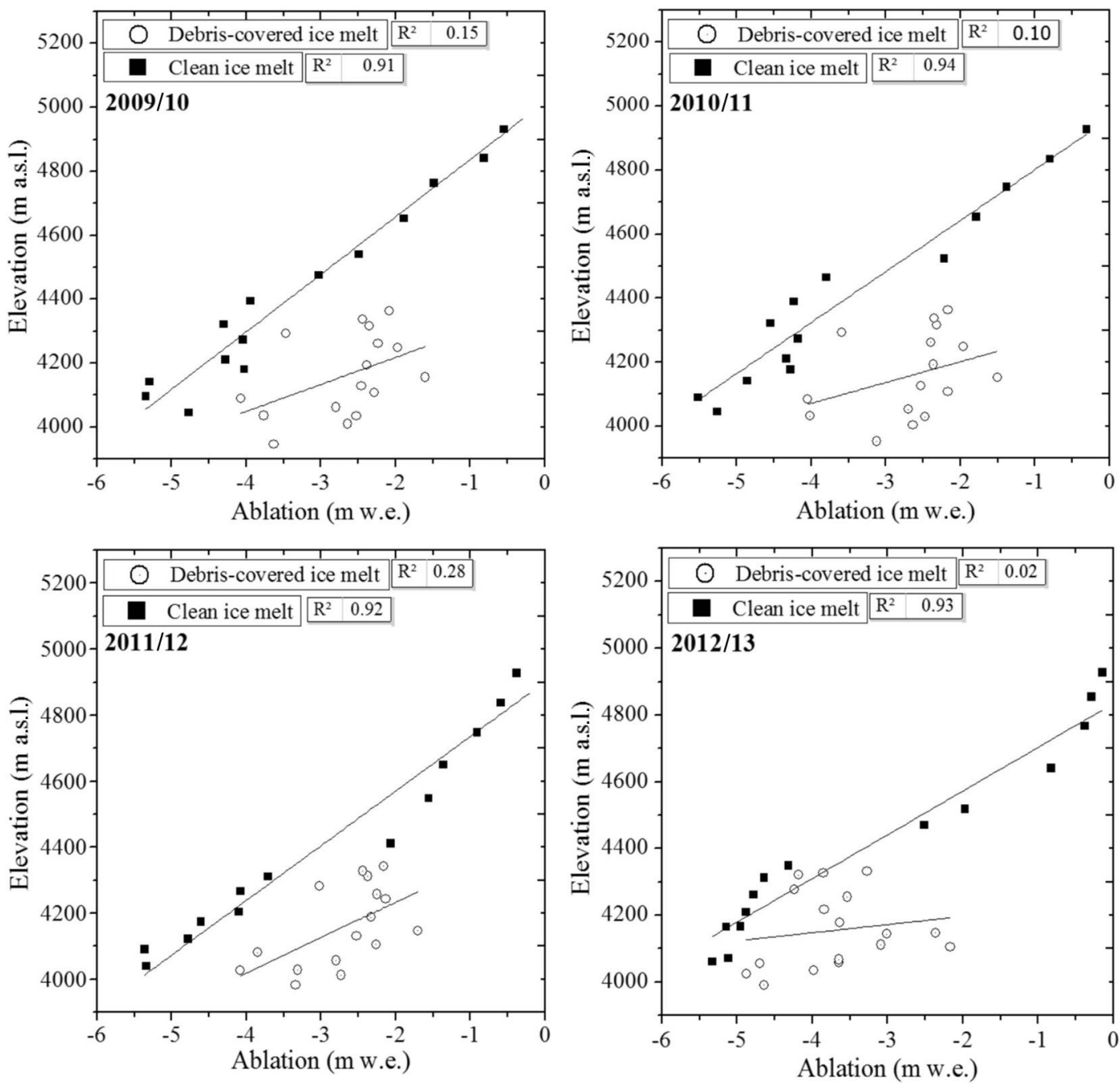

Fig. 3. Annual ablation profile for debris-covered and clean ice of Dokriani Glacier during 2009/10-2012/13.

Substantial ice melting during 2012/13 progressively narrowed down the glacier centre line, rendering the debris along the side margins of the glacier highly unstable and eventually sluicing it into the $10 \mathrm{~m}$ deep supraglacial stream channel (Fig. 4; Table 1). A sudden change in ablation pattern of Dokriani Glacier due to epiglacial morphology change has also been reported (Dobhal and others 2008; Dobhal and Mehta, 2010).

\section{Spatial variations in debris thickness and melting}

The ablation area of Dokriani Glacier was covered with debris varying in thickness between 1 and $40 \mathrm{~cm}$ (Fig. 1). The average value was $9 \mathrm{~cm}$ based on in situ survey at the end of each ablation period during 2009/10-2012/13. The pattern of monthly ablation of debris-covered ice was highly variable in each year (Fig. 5). June-September was the period with maximum melting during 2009/10-2012/13. This period is known as the peak summer melting season, with maximum melting occurring in July. Overall, monthly melt rates of ice covered with debris of varying thickness at different elevations show significant variations among the studied balance years (Fig. 5). This is due to differences in seasonal meteorological conditions (e.g. quantity of insulation, snowline depletion, temperature and precipitation).

Previous work on the sub-debris melt rate (an empirical measurement of the relationship between debris thickness and ice ablation rate, known as the Østrem curve) has determined the gain or loss in ablation rate (Østrem, 1959; Nicholson and Benn, 2006). Those results demonstrate increased ice ablation under $1-2 \mathrm{~cm}$, and equal ablation under $2-4 \mathrm{~cm}$, of debris thickness compared to clean ice. Unlike the increase in melting rate up to a certain debris thickness in the Østrem curve, we found asymptotic decline in ablation rate under thin debris cover $(1-2 \mathrm{~cm})$ compared to clean ice (Figs 3 and 6). Our study, based on the annual exponential curve relationship of debris thickness and melt

Table 1. Observed annual ablation on Dokriani Glacier for adjacent debris-covered ice and clean ice between 3900 and 4400 ma.s.l.

\begin{tabular}{lccc}
\hline Year & Clean-ice melting & $\begin{array}{c}\text { Debris-covered } \\
\text { ice melting }\end{array}$ & Difference \\
& mw.e. & mw.e. & $\%$ \\
\hline $2009 / 10$ & -4.51 & -2.70 & 40 \\
$2010 / 11$ & -4.65 & -2.64 & 44 \\
$2011 / 12$ & -4.32 & -2.70 & 37 \\
$2012 / 13$ & -5.22 & -3.81 & 27 \\
Total & $\mathbf{- 1 8 . 7}$ & $\mathbf{- 1 1 . 8 5}$ & $\mathbf{3 7}$ \\
\hline
\end{tabular}



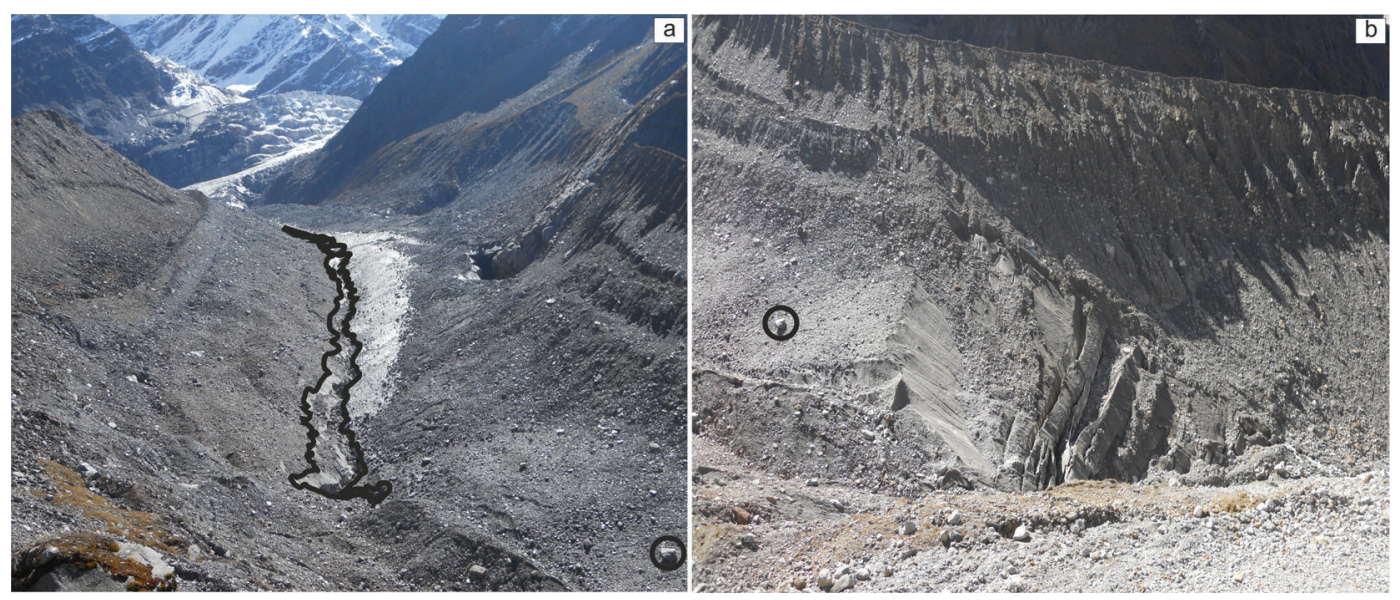

Fig. 4. (a) Recent (2013) formation of supraglacial stream channel along the centre line to nearby snout of Dokriani Glacier. (b) Fragmentation of glacier snout due to higher melting at clean-ice upper surface compared to thick debris-covered lower part.

rate, reports moderate correlation coefficients $\left(R^{2}\right)$ ranging from 0.45 to 0.73 during $2009 / 10$ to $2012 / 13$ (Fig. 6). The low statistical relationship during 2010-12 is attributed to lower melt rate at higher elevation compared to a lower ablation zone under similar debris thickness. Surprisingly, we found high correlation coefficients $\left(R^{2}=0.73\right)$ during 2012/13 when supraglacial streamflows significantly increased ice melt (Fig. 6). For debris-covered ice, melting was maximum $\left(4.0 \mathrm{mw}\right.$.e. $\left.\mathrm{a}^{-1}\right)$ for $1-6 \mathrm{~cm}$ of debris, abruptly decreasing by $11 \%$ (to $3.6 \mathrm{mw}$.e. $\mathrm{a}^{-1}$ ) for $\sim 9 \mathrm{~cm}$ of debris and reaching a minimum $\left(1.6 \mathrm{mw}\right.$.e. $\left.\mathrm{a}^{-1}\right)$ at $40 \mathrm{~cm}$ of debris (Fig. 6). The stakes drilled at 4025-50 and 4325-50 m a.s.l. with similar debris thickness $(5-7 \mathrm{~cm})$ show variation in ablation rate (Fig. 6). Ablation decreased by $36 \%$ at higher-elevation (4325-50 ma.s.l.) stakes as compared to lower-elevation stakes (4025-50 ma.s.l.). This suggests that altitude influences the impact of debris cover on glacier ice melting, as mentioned by previous studies (e.g. Reznichenko and others, 2010; Fyffe and others, 2014).

Our analysis shows that an increase in debris thickness reduces the rate of ice ablation and protects the ice underneath from melting. This is in conformity with many field-based short-term studies in the Himalaya (e.g. of Khumbu and Lirung glaciers, Nepal Himalaya (Rana and others, 1998; Kayastha and others, 2000), Chorabari Glacier, Garhwal Himalaya (Dobhal and others, 2013), and Barpu Glacier, Pakistan (Khan, 1989)) (Table 2). Mattson and others (1993) reported an ablation increase under $0-10 \mathrm{~mm}$ of
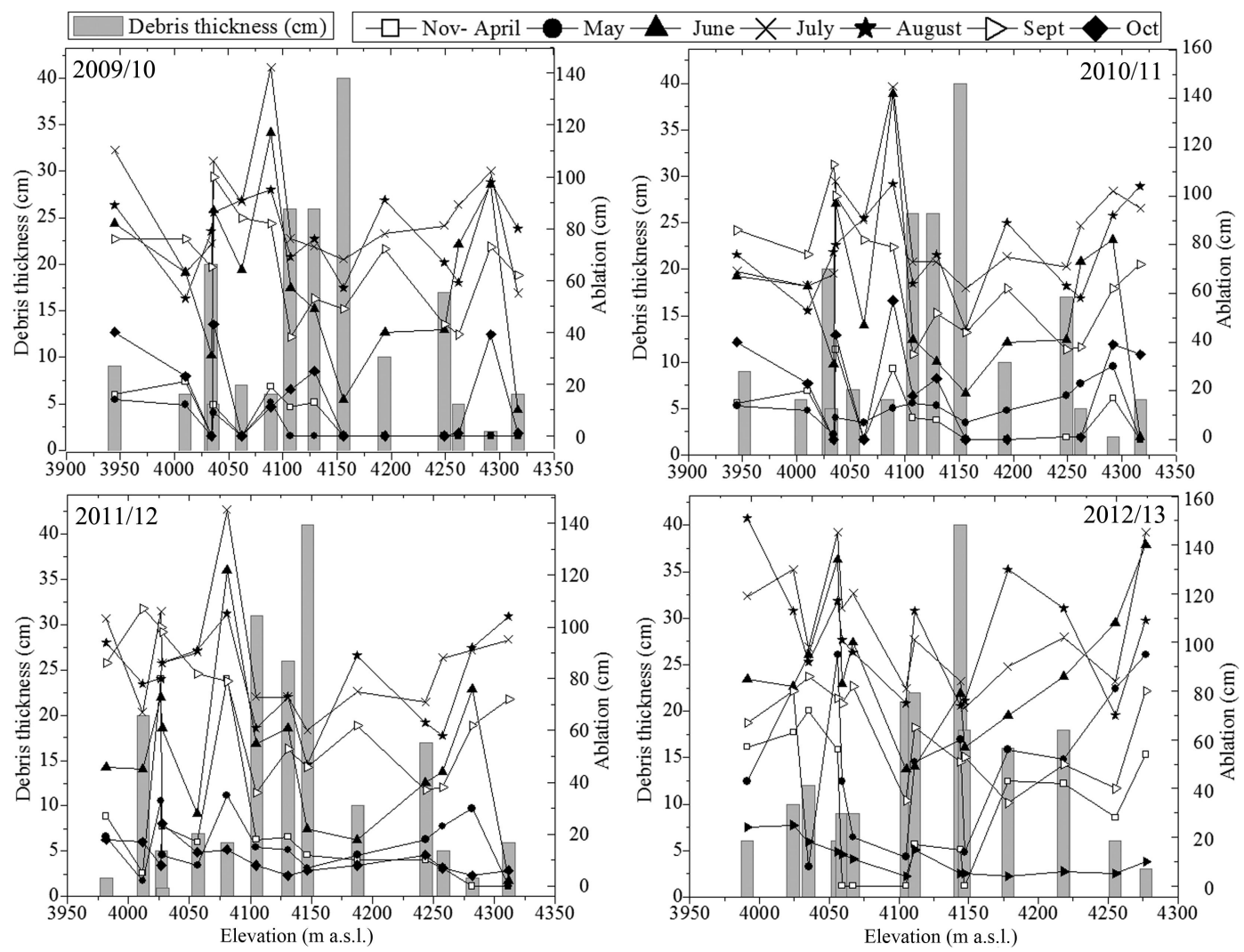

Fig. 5. Spatial distributions of debris-cover thickness and associated monthly melting during 2009/10-2012/13. 


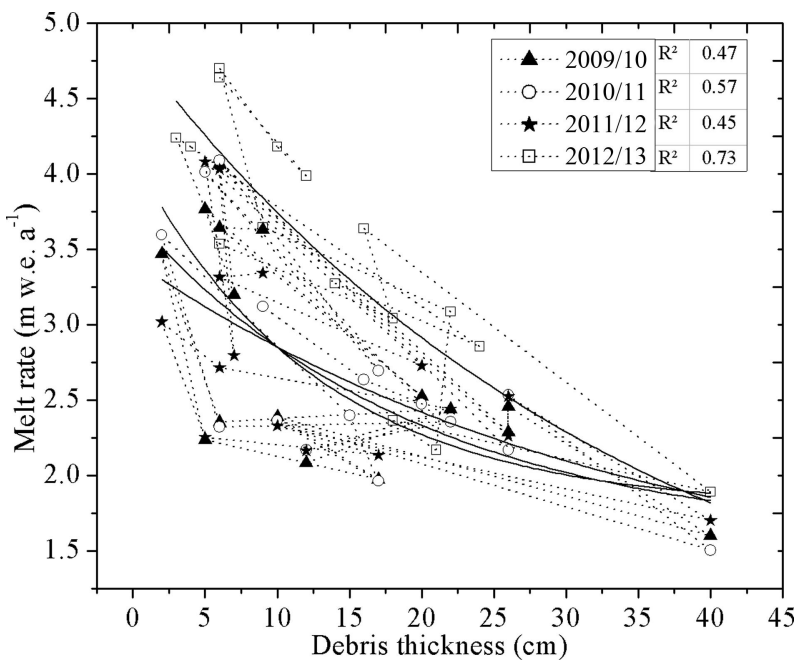

Fig. 6. Exponential curve relationship between debris thickness and annual ablation during 2010-13. Dotted line connected to markers displays ablation stake observation from snout to higher ablation zone.

debris on debris-covered Rakhiot Glacier based on an in situ survey from 22 June to 8 August 1986 (Table 2). Conversely, our study presented long-term (4 years) monthly summer ablation, as well as cumulative winter ablation, which sheds more light on monthly variation between debris thickness and the ablation process.

\section{CONCLUSION}

We have reported surface melting conditions on Dokriani Glacier from 2009/10 to 2012/13. We found high correlation $\left(R^{2}=0.92\right)$ between the mean annual ablation of clean ice and altitude, and very low correlation $\left(R^{2}=0.14\right)$ between the mean annual ablation of debris-covered ice and altitude. This difference can be attributed to the insulation effect of inhomogeneous distribution of debris thickness with respect to altitude. Maximum clean-ice melting $\left(4.9 \mathrm{mw}\right.$.e. $\left.\mathrm{a}^{-1}\right)$ was observed near the snout and found to be linearly decreasing with elevation increase, reaching $0.34 \mathrm{~m}$ w.e. $\mathrm{a}^{-1}$ between 4900 and $5000 \mathrm{~m}$ a.s.l.

Conversely, debris-covered ice melting was found to be inhomogeneous with altitude, but melting decreased as debris thickness increased. We found that even ice covered with $1-2 \mathrm{~cm}$ of debris has less melting as compared to cleanice melting for every studied year (2009/10-2012/13). Our results suggest that debris-covered ice has significantly lower melting rates than clean ice during the study period. An analysis based on monthly ablation over debris-covered area also shows variability with altitude for every studied balance year. This is due to differences in monthly atmospheric conditions.

In addition, ablation data suggest that the supraglacial debris-covered area is continuously accompanied by debris at higher elevation. The debris that particularly accumulates in the lower ablation zone due to substantial clean-ice melting now reduces the ice melt. These results imply that the lower part of glacier response becomes less sensitive to climate. Therefore, we conclude that the substantial icesurface loss in the recent warm period is gradually increasing the debris cover in the ablation zone and insulating ice melt underneath.

\section{ACKNOWLEDGEMENTS}

We are grateful to A.K. Gupta, Director, Wadia Institute of Himalayan Geology (WIHG), for providing facilities and ample support to carry out this work. We thank Kishor Kumar of WIHG and the anonymous reviewers for valuable comments and suggestions which improved the manuscript. We are also grateful to the Department of Science and Technology (DST), Government of India, New Delhi, for financial support.

\section{REFERENCES}

Adhikary S, Nakawo M, Seko K and Shakya B (2000) Dust influence on the melting process of glacier ice: experimental results from Lirung Glacier, Nepal Himalayas. IAHS Publ. 264 (Symposium at Seattle 2000 - Debris-Covered Glaciers), 43-52

Basnett S, Kulkarni AV and Bolch T (2013) The influence of debris cover and glacial lakes on the recession of glaciers in Sikkim Himalaya, India. J. Glaciol., 59(218), 1035-1046 (doi: 10.3189/ 2013JoG12J184)

Benn DI and 9 others (2012) Response of debris-covered glaciers in the Mount Everest region to recent warming, and implications for outburst flood hazards. Earth-Sci. Rev., 114(1-2), 156-174 (doi: 10.1016/j.earscirev.2012.03.008)

Berthier E, Arnaud Y, Kumar R, Ahmad S, Wagnon P and Chevallier $P$ (2007) Remote sensing estimates of glacier mass balances in the Himachal Pradesh (Western Himalaya, India). Remote Sens. Environ., 108(3), 327-338 (doi: 10.1016/j.rse.2006.11.017)

Bhambri R, Bolch T and Chaujar RK (2011) Mapping of debriscovered glaciers in the Garhwal Himalayas using ASTER DEMs and thermal data. Int. J. Remote Sens., 32(23), 8095-8119 (doi: 10.1080/01431161.2010.532821)

Table 2. Summary of field-based observation of supraglacial debris thickness and critical thickness for ablation underneath Himalayan glaciers

\begin{tabular}{|c|c|c|c|c|c|}
\hline Glacier & Observation period & $\begin{array}{l}\text { Debris thickness } \\
\qquad \mathrm{cm}\end{array}$ & $\begin{array}{l}\text { Critical thickness } \\
\text { mm }\end{array}$ & Region & Source \\
\hline Khumbu & 21 May to 1 June 1999 & $0-40$ & 50 & $\begin{array}{l}\text { Everest Base Camp } \\
\text { (5350 m a.s.l.), Nepal }\end{array}$ & $\begin{array}{l}\text { Kayastha and others } \\
\qquad(2000)\end{array}$ \\
\hline Lirung & 18 to 21 June 1995 & $0-13$ & 80 & Langtang Valley, Nepal & Rana and others (1998) \\
\hline Rakhiot & 22 June to 8 August 1986 & $0-40$ & 30 & Punjab Himalaya & Mattson and others (1993) \\
\hline Dokriani & 1 November 2009 to 31 October 2013 & $0-40$ & - & Uttarakhand, Himalaya & Present study \\
\hline Barpu & 26 May to 19 July 1987 & $0-70$ & 25 & Pakistan, Himalaya & Khan (1989) \\
\hline
\end{tabular}


Bhambri R, Bolch T and Chaujar RK (2012) Frontal recession of Gangotri Glacier, Garhwal Himalayas, from 1965 to 2006, measured through high-resolution remote sensing data. Current Sci., 102(3), 489-494

Bolch T, Buchroithner M, Pieczonka T and Kunert A (2008) Planimetric and volumetric glacier changes in the Khumbu Himal, Nepal, since 1962 using Corona, Landsat TM and ASTER data. J. Glaciol., 54(187), 592-600 (doi: 10.3189/ 002214308786570782)

Bolch T, Pieczonka T and Benn DI (2011) Multi-decadal mass loss of glaciers in the Everest area (Nepal Himalaya) derived from stereo imagery. Cryosphere, 5(2), 349-358 (doi: 10.5194/tc-5349-2011)

Casey KA, Kääb A and Benn DI (2012) Geochemical characterization of supraglacial debris via in situ and optical remote sensing methods: a case study in Khumbu Himalaya, Nepal. Cryosphere, 6(1), 85-100 (doi: 10.5194/tc-6-85-2012)

Cogley JG and 10 others. (2011) Glossary of glacier mass balance and related terms. (IHP-VII Technical Documents in Hydrology 86) UNESCO-International Hydrological Programme, Paris

Dobhal DP and Mehta M (2010) Surface morphology, elevation changes and terminus retreat of Dokriani Glacier, Garhwal Himalaya: implication for climate change. Himalayan Geol., 31(1), 71-78

Dobhal DP, Gergan JG and Thayyen RJ (2004) Recession and morphogeometrical changes of Dokriani glacier (1962-1995), Garhwal Himalayas, India. Current Sci., 86(5), 692-696

Dobhal DP, Gergan JT and Thayyen RJ (2008) Mass balance studies of the Dokriani Glacier from 1992 to 2000, Garhwal Himalaya, India. Bull. Glaciol. Res., 25, 9-17

Dobhal DP, Mehta M and Srivastava D (2013) Influence of debris cover on terminus retreat and mass changes of Chorabari Glacier, Garhwal region, central Himalaya, India. J. Glaciol., 59(217), 961-971 (doi: 10.3189/2013JoG12J180)

Fyffe $\mathrm{CL}$ and 6 others (2014) A distributed energy-balance melt model of an alpine debris-covered glacier. J. Glaciol., $60(221)$, 587-602 (doi: 10.3189/2014JoG13J148)

Hambrey MJ, Bennett MR, Dowdeswell JA, Glasser NF and Huddart D (1999) Debris entrainment and transfer in polythermal valley glaciers. J. Glaciol., 45(149), 69-86

Hewitt K (2009) Rock avalanches that travel onto glaciers and related developments, Karakoram Himalaya, Inner Asia. Geomorphology, 103(1), 66-79 (doi: 10.1016/j.geomorph.2007.10.017)

Kayastha RB, Takeuchi Y, Nakawo M and Ageta Y (2000) Practical prediction of ice melting beneath various thickness of debris cover on Khumbu Glacier, Nepal using a positive degree-day factor. IAHS Publ. 264 (Symposium at Seattle 2000 - DebrisCovered Glaciers), 71-81

Khan MI (1989) Ablation on Barpu Glacier, Karakoram Himalaya, Pakistan: a study of melt processes on a faceted, debris-covered ice surface. (MSc thesis, Wilfrid Laurier University)

Kirkbride M (1995) Ice flow vectors on the debris-mantled Tasman Glacier, 1957-1986. Geogr. Ann. A, 77(3), 147-157

Kirkbride MP and Dugmore AJ (2003) Glaciological response to distal tephra fallout from the 1947 eruption of Hekla, south Iceland. J. Glaciol., 49(166), 420-428 (doi: 10.3189/ 172756503781830575)

Kulkarni AV and 6 others (2007) Glacial retreat in Himalaya using Indian remote sensing satellite data. Current Sci., 92(1), 69-74

Kulkarni AV, Rathore BP, Singh SK and Bahuguna IM (2011) Understanding changes in the Himalayan cryosphere using remote sensing techniques. Int. J. Remote Sens., 32(3), 601-615 (doi: 10.1080/01431161.2010.517802)

Mattson LE (2000) The influence of a debris cover on the midsummer discharge of Dome Glacier, Canadian Rocky Mountains. IAHS Publ. 264 (Symposium in Seattle 2000 - DebrisCovered Glaciers), 25-33

Mattson LE, Gardner JS and Young GJ (1993) Ablation on debris covered glaciers: an example from the Rakhiot Glacier, Punjab,
Himalaya. IAHS Publ. 218 (Symposium at Kathmandu $1992-$ Snow and Glacier Hydrology), 289-296

Mayewski PA and Jeschke PA (1979) Himalayan and transHimalayan glacier fluctuations since A.D. 1812. Arct. Alp. Res., 11(3), 267-287

Moribayashi S and Higuchi K (1977) Characteristics of glaciers in Khumbu region and their recent variations. Seppyo, J. Jpn. Soc. Snow lce, 39, 3-6

Nicholson L and Benn DI (2006) Calculating ice melt beneath a debris layer using meteorological data. J. Glaciol., 52(178), 463-470 (doi: 10.3189/172756506781828584)

Nicholson L and Benn DI (2013) Properties of natural supraglacial debris in relation to modelling sub-debris ice ablation. Earth Surf. Process. Landf., 38(5), 490-501 (doi: 10.1002/esp.3299)

Østrem G (1959) Ice melting under a thin layer of moraine, and the existence of ice cores in moraine ridges. Geogr. Ann., 41(4), 228-230

Østrem G and Brugman M (1991) Glacier mass-balance measurements: a manual for field and office work. (NHRI Science Report 4) National Hydrology Research Institute, Environment Canada, Saskatoon, Sask.

Pratap B, Dobhal DP, Bhambri R and Mehta M (2013) Near-surface temperature lapse rate in Dokriani Glacier catchment, Garhwal Himalaya, India. Himalayan Geol., 34(2), 183-186

Racoviteanu AE, Williams MW and Barry RG (2008) Optical remote sensing of glacier characteristics: a review with focus on the Himalaya. Sensors, 8(5), 3355-3383 (doi: 10.3390/s8053355)

Raina VK (2009) Himalayan glaciers: a state-of-art review of glacial studies, glacial retreat and climate change. (MoEF Discussion Paper) Ministry of Environment and Forests, Government of India/G.B. Pant Institute of Himalayan Environment and Development, New Delhi/Kosi-Katarmal, Almora http://go.nature. com/pLgJ6D

Rana B, Nakawo M, Ageta Y, Seko K, Kubota J and Kojima A (1998) Glacier ablation under debris cover: field observations on Lirung Glacier, Nepal Himalayas. In Proceedings of the International Conference on Ecohydrology of High Mountain Areas, 2428 March 1996, Kathmandu, Nepal. International Centre for Integrated Mountain Development, Kathmandu, 393-403

Reznichenko N, Davies T, Shulmeister J and McSaveney MJ (2010) Effects of debris on ice-surface melting rates: an experimental study. J. Glaciol., 56(197), 384-394 (doi: 10.3189/ 002214310792447725)

Sakai A, Takeuchi N, Fujita K and Nakawo M (2000) Role of supraglacial ponds in the ablation process of a debris-covered glacier in the Nepal Himalayas. IAHS Publ. 264 (Symposium at Seattle 2000 - Debris-Covered Glaciers), 119-130

Scherler D, Bookhagen B and Strecker MR (2011) Spatially variable response of Himalayan glaciers to climate change affected by debris cover. Nature Geosci., 4(3), 156-159 (doi: 10.1038/ ngeo1068)

Shroder JF, Bishop MP, Copland L and Sloan VF (2000) Debriscovered glaciers and rock glaciers in the Nanga Parbat Himalaya, Pakistan. Geogr. Ann. A, 82(1), 17-31 (doi: 10.1111/j.0435-3676.2000.00108.x)

Shukla A, Gupta RP and Arora MK (2009) Estimation of debris cover and its temporal variation using optical satellite sensor data: a case study in Chenab basin, Himalaya. J. Glaciol., 55(191), 444-452 (doi: 10.3189/002214309788816632)

Singh P, Kumar N, Ramasastri KS and Singh Y (2000) Influence of a fine debris layer on the melting of snow and ice on a Himalayan glacier. IAHS Publ. 264 (Symposium at Seattle 2000 - DebrisCovered Glaciers), 63-70

Singh P, Haritashya UK and Kumar N (2007) Meteorological study for Gangotri Glacier and its comparison with other high altitude meteorological stations in central Himalayan region. Nord. Hydrol., 38(1), 59-77 (doi: 10.2166/nh.2007.028)

Thayyen RJ and Gergan JT (2010) Role of glaciers in watershed hydrology: a preliminary study of a 'Himalayan catchment'. Cryosphere, 4(1), 115-128 (doi: 10.5194/tc-4-115-2010) 
Thayyen RJ, Gergan JT and Dobhal DP (2005) Monsoonal control on glacier discharge and hydrograph characteristics, a case study of Dokriani Glacier, Garhwal Himalaya, India. J. Hydrol., 306(1-4), 37-49 (doi: 10.1016/j.jhydrol.2004.08.034)

Valdiya KS, Paul SK, Chandra T, Bhakuni SS and Upadhyay RC (1999) Tectonic and lithological characterization of Himadri
(Great Himalaya) between Kali and Yamuna rivers, Central Himalaya. Himalayan Geol., 20(2), 1-17

Zhang G, Xie H, Kang S, Yi D and Ackley SF (2011) Monitoring lake level changes on the Tibetan Plateau using ICESat altimetry data (2003-2009). Remote Sens. Environ., 115(7), 1733-1742 (doi: 10.1016/j.rse.2011.03.005) 